\title{
ANALISIS SURVIVAL DALAM MEMPREDIKSI KONDISI FINANCIAL DISTRESS
}

\author{
Muhammad Sanyasa Tyaga ${ }^{1}$ \\ Farida Titik Kristanti ${ }^{2}$
}

\begin{abstract}
Fakultas Ekonomi dan Bisnis Universitas Telkom, Jawa Barat, Indonesia ${ }^{1,2}$
Email: sanyasatyaga@gmail.com¹ Telp: 082128120665
\end{abstract}

\begin{abstract}
Survival Analysis In Predicting Financial Distress Conditions. Companies are required to be able to maintain the survival of the company so that the company's goals can be achieved properly. Financial distress is one of the factors that causes companies to not be able to maintain their survival so that the company's goals are not achieved. Factors that cause the company is in a state of distress are internal and external factors. This study uses internal factors such as financial ratios, size, agency costs and external factor is inflation. This research method is a quantitative method using time series data. The regression model used is the cox proportional hazard regression model. Determination of the sample using purposive sampling so that 81 samples were used in this study. Based on the results of partial tests, leverage, liquidity, activity, company size, managerial agency costs do not have a significant effect on financial distress. Only inflation has a significant positive effect on financial distress.
\end{abstract}

Keywords: Financial Ratios; Size; Agency Costs; Inflation; Financial Distress.

Abstrak: Analisis Survival Dalam Memprediksi Kondisi Financial Distress. Perusahaan dituntut untuk dapat mempertahankan kelangsungan hidupnya agar tujuan perusahaan dapat tercapai dengan baik. Financial distress merupakan salah satu faktor yang menyebabkan perusahaan tidak dapat mempertahankan kelangsungan hidupnya sehingga tujuan perusahaan tidak tercapai. Faktor-faktor yang menyebabkan perusahaan sedang dalam kondisi distress adalah faktor internal dan eksternal. Penelitian ini menggunakan faktor internal berupa rasio keuangan, ukuran, biaya agensi serta faktor eksternalnya adalah inflasi. Metode penelitian ini adalah metode kuantitatif dengan menggunakan data time series. Model regresi yang digunakan adalah model regresi cox proportional hazard. Penentuan sampel menggunakan purposive sampling sehingga 81 sampel digunakan dalam penelitian ini. Berdasarkan hasil uji parsial, leverage, likuiditas, aktivitas, ukuran perusahaan, biaya agensi manajerial tidak memiliki pengaruh signifikan terhadap financial distress. Hanya inflasi yang memiliki pengaruh positif signifikan terhadap financial distress.

Kata Kunci: Rasio Keuangan; Ukuran; Biaya Agensi; Inflasi; Financial Distress. 


\section{PENDAHULUAN}

Perusahaan dituntut untuk dapat mempertahankan kelangsungan hidup perusahaan sehingga tujuan perusahaan dapat tercapai dengan baik. Masuknya pesaing membuat perusahaan harus termotivasi untuk membuat strategi agar dapat bergerak maju dan menjaga stabilitas perusahaan. Tidak hanya masuknya pesaing, perubahan ekonomi, politik, sosial dan budaya dan kebijakan pemerintah juga dapat mempengaruhi kelangsungan hidup perusahaan. Ketika sebuah perusahaan tidak dapat bersaing dengan para pesaingnya, dan tidak dapat mengikuti perubahan yang terjadi di negara tersebut, maka perusahaan tersebut kemungkinan akan mengalami kesulitan keuangan atau yang biasa disebut dengan financial distress.

Financial distress adalah tahap di mana perusahaan mengalami penurunan pada kondisi keuangan, tahap ini biasanya terjadi sebelum perusahaan bangkrut atau dilikuidasi (Platt \& Platt, 2002). Definisi lainnya mengenai financial distress adalah keadaan dimana keuangan dari perusahaan tersebut sedang tidak sehat atau krisis (Moleong, 2018). Fokus dari manajemen sebuah perusahaan akan terpecah belah apabila keadaan keuangan yang dialami peusahaan tidak sehat, seharusnya manajemen perusahaan fokus untuk menarik pelanggan dan supplier agar tujuan perusahaannya tercapai dengan baik tetapi apabila kondisi keuangannya tidak sehat, manajemen perusahaan akan lebih fokus pada penyelesaian masalah keuangan perusahaan itu sendiri (Cinantya \& Merkusiwati, 2015).

Kristanti (2019;13-14) menyatakan bahwa ada dua penyebab financial distress, yaiu masalah internal dan eksternal perusahaan. Salah satu penyebab internal adalah ketidakmampuan perusahaan dalam mengelola dan mempertahankan kestabilan kinerja keuangan perusahaan sehingga perusahaan mengalami kerugian opersional serta kerugian bersih untuk tahun berjalan. Kemudian, dari kerugian bersih yang dialami perusahaan itu akan mengakibatkan defisiensi modal karena saldo laba yang didapat menurun dan ada kemungkinan perusahaan tidak dapat membayarkan dividennya kepada para investor (Christine, Wijaya, Chandra, \& Pratiwi, 2019). Apabila suatu perusahaan mengumumkan bahwa kondisi perusahaannya mengalami distress, para investor dan kreditor harus waspada pada investasinya begitu juga pada 
kredit yang dipinjamkan. Oleh karena itu, terdaftar di Bursa Efek Indonesia. Industri untuk mengamankan kredit dan investasi yang manufaktur merupakan salah satu penopang dikelola perusahaan, diperlukan strategi yang pada perekonomian nasional serta berkontribusi baik untuk mencegah kondisi financial distress paling banyak pada pertumbuhan ekonomi bagi manajemen perusahaan itu sendiri (Purba, di Indonesia. Menurut Menteri perindustrian 2019).

kabinet kerja Airlangga Hartarto, industri

Untuk mengukur kondisi financial manufaktur merupakan tulang punggung bagi distress, dapat digunakan ukuran Earning ekonomi nasional serta menjadi indutsri andalan Per Share (EPS). Menurut Elloumi \& Gueyie (2001), EPS dapat menunjukkan keadaan suatu perusahaan yang sedang mengalami distress, jika suatu perusahaan memiliki EPS yang bernilai negatif dapat dikatakan perusahaan tersebut sedang mengalami distress sedangkan sebaliknya, jika perusahaan memiliki EPS yang bernilai positif dapat dikatakan perusahaan tersebut tidak mengalami. Pada penelitian ini, untuk menilai financial distress dapat menggunakan variabel dummy, artinya jika perusahaan memiliki EPS bernilai negatif diberi nilai 1 sedangkan jika perusahaan memiliki EPS bernilai positif diberi nilai 0 (Kristanti, Rahayu, \& Huda, 2016).

Penelitian ini menggunakan sektor aneka industri dan sektor industri dasar kimia sebagai objek penelitian. Kedua sektor tersebut termasuk dalam industri manufaktur yang dalam memacu pemerataan pembangunan dan kesejahteraan masyarakat yang inklusif (www.kemenperin.go.id). Namun, dilihat dari pertumbuhan EPS kedua sektor tersebut di tahun 2009-2018, terdapat beberapa subsektor dari kedua sektor tersebut yang mengalami penurunan EPS yang signifikan. Meskipun ada subsektor yang memiliki peningkatan pada EPS nya, rata-rata pertumbuhan EPS yang terlihat pada Tabel 1 menurun.

Berdasarkan Tabel 1, EPS dari tahun ke tahun mengalami fluktuasi setiap tahunnya. Pergerakkan fluktuaktif menunjukkan dominan EPS yang menurun. Subsektor yang cukup terlihat pada EPS yang menurun yaitu subsektor alas kaki (footwear), automotive, tekstil dan garmen. Subsektor alas kaki terdiri dari dua perusahaan, perusahaan yang mengakibatkan EPS subsektor turun adalah PT Sepatu Bata 
Tabel 1.

Pertumbuhan EPS pada Perusahaan Aneka Industri dan Industri Dasar Kimia Tahun 2009-2018

\begin{tabular}{lcccccccccc}
\hline & \multicolumn{7}{c}{ Rata-rata nilai EPS (Dalam satuan Rupiah) } \\
$\begin{array}{l}\text { Subsektor di } \\
\text { Sektor Aneka } \\
\text { Industri }\end{array}$ & 2009 & 2010 & 2011 & 2012 & 2013 & 2014 & 2015 & 2016 & 2017 & Sep- \\
Mesin & & & & & & & & & & 2018 \\
\hline Automotif & 538 & 872 & 858 & 606 & 309 & 66 & -137 & -127 & 47 & 136 \\
\hline Tekstil & -55 & -284 & 200 & -1295 & -140 & 129 & 118 & -46 & -40 & 132 \\
\hline Alas Kaki & 4218 & 4796 & 4383 & 2835 & -45 & 131 & -49 & 30 & 23 & 24 \\
\hline Kabel & 47 & 52 & 166 & 252 & 158 & 224 & 120 & 521 & 366 & 338 \\
\hline Eleckronik & -20 & -9 & -4 & 3 & 8 & -7 & 3 & 1.48 & 8 & 73 \\
\hline $\begin{array}{l}\text { Subsektor di } \\
\text { Sektor Industri }\end{array}$ & 2009 & 2010 & 2011 & 2012 & 2013 & 2014 & 2015 & 2016 & 2017 & Sep- \\
$\begin{array}{l}\text { Dasar dan } \\
\text { Kimia }\end{array}$ & & & & & & & & & & 2018 \\
\hline Semen & 439 & 513 & 594 & 619 & 579 & 486 & 374 & 307 & 138 & 111 \\
\hline $\begin{array}{l}\text { Keramic, } \\
\text { Porselain, Kaca }\end{array}$ & 790 & 876 & 1033 & 202 & 159 & 296 & 139 & 104 & 18 & 4 \\
\hline $\begin{array}{l}\text { Logam dan } \\
\text { sejenisnya }\end{array}$ & 315 & 160 & 316 & 566 & 63 & 129 & 13 & 28 & 24 & 16 \\
\hline Kimia & 114 & 57.2 & 28 & -4 & 61 & 61 & 18 & 250 & 78 & 113 \\
\hline Plastik & 54 & 49 & 78 & 17 & 8 & 47 & 14 & 20 & -5 & 26 \\
\hline Pakan ternak & 249 & 242 & 221.6 & 257 & 117 & 49 & -83 & 145 & -11 & 128 \\
\hline Kayu & -59 & -8.5 & -114 & -70 & -103 & 20 & -51 & 58 & 7 & -26 \\
\hline Pulp dan Kertas & 9 & 138.28 & 81.655 & 43 & 28 & 73 & 57 & 133 & 153 & 461 \\
\hline
\end{tabular}

Sumber: IDX. Data diolah (2020).

Tbk. EPS yang dimiliki oleh PT Sepatu Bata drastis dari tahun 2011 sebesar Rp1.033,00 Tbk di tahun 2008 sebesar Rp12.120,00 menjadi Rp202,00 di tahun 2012. Subsektor kemudian di tahun 2009 mengalami penurunan lainnya yang mengalami penurunan adalah drastis menjadi Rp4.075,00 hingga sampai di subsektor semen. Subsektor semen mengalami tahun 2018 sebesar Rp52,27. Subsektor tekstil penurunan tiap tahunnya dari tahun 2011 sampai dan garmen memiliki pergerakan dominan di tahun 2018. Subsektor logam dan sejenisnya angka negatif. Sedangkan pada sektor industri pun mengalami penurunan EPS yang drastis dari dasar dan kimia, terlihat banyak subsektor dari tahun 2012 sebesar Rp566,00 menjadi Rp63,00 sektor industri dasar dan kimia yang mengalami di tahun 2013 serta selanjutnya mengalami penurunan EPS. Subsektor keramik, porselen penurunan yang signifikan sampai tahun 2018. dan kaca menunjukkan penurunan EPS yang Subsektor kayu dan pengolahannya bergerak 
fluktuaktif di angka negatif hingga akhirnya di tahun 2016 memperoleh EPS bernilai positif, hanya di tahun 2017 dan 2018, EPS nya menurun menuju angka negatif. Dari seluruh pergerakan EPS pada sektor industri dasar dan kimia, hanya subsektor pulp dan kertas yang menunjukkan kenaikan pada EPSnya. Keadaan yang tidak baik ini sering terjadi di beberapa tahunnya sehingga jika nilai EPS menurun sebagaimana telah disebutkan sebelumnya akan mengarah pada kondisi distress.

Financial distress dapat ditentukan melalui rasio keuangan perusahaan tersebut. Rasio keuangan dapat menjelaskan kinerja keuangan suatu perusahaan yang sebenarnya (Agustini \& Wirawati, 2019). Prediksi kondisi financial distress dapat menggunakan analisis rasio laporan keuangan, hasil analisis tersebut dapat dijadikan bahan dalam proses pengambilan keputusan dan penentuan kebijakan bagi investor dan manajer (Widhiari \& Merkusiwati, 2015). Apabila perusahaan dikatakan sehat, perusahaan tersebut akan memperlihatkan kemampuannya dalam melaksanakan aktivitasnya, mendistribusikan aktivanya, memanfaatkan aktivanya secara optimal, melunasi beban yang harus dibayar saat jatuh tempo, serta dapat mengetahui kemungkinan kondisi distress yang akan dialami (Brahmana, 2007).

Terdapat dua teori utama dalam penelitian financial distress. Teori pertama adalah teori sinyal. Teori sinyal menjelaskan kondisi yang sedang dialami oleh perusahaan dan bagaimana tindakan yang diambil oleh manajemen dalam menyampaikan kondisi perusahaan sebagai informasi kepada investor dan kreditor (Pertiwi, 2018). Teori sinyal menjelaskan dengan cara apa pemakai laporan keuangan menerima sinyal-sinyal dari perusahaan. Sinyal bisa dalam bentuk akuisisi manajemen yang baik dalam mewujudkan kebijakan pemegang saham (Muflihah, 2017). Teori yangkedua adalah teori agensi. Teori agensi adalah menejelaskan hubungan yang erat antara kontrak satu orang atau lebih (principal) dengan melibatkan orang lain (agent) untuk melakukan beberapa pelayanan atas nama principal dengan melibatkan pelimpahan wewenang kepada agent (Rimawati \& Darsono, 2017). Teori agensi menekankan bahwa pemegang saham dalam suatu perusahaan adalah sebuah hal yang penting dalam memberikan pengelolaan perusahaan kepada agent yang lebih mengerti 
dalam mengelola dan mengoperasikan sebuah bisnis (Prastiwi \& Dewi, 2019).

Rasio keuangan yang dipakai dalam penelitian ini yaitu rasio leverage. Rasio leverage dapat diartikan sebagai rasio yang menilai bagaimana kegiatan perseroan dibebani dengan utang. Banyaknya utang yang dimiliki perusahaan akan membahayakan karena perusahaan bisa masuk pada kategori utang ekstrem dimana perusahaan dapat terlibat dalam utang yang tinggi dan berat untuk membayar beban utang tersebut (Fahmi, 2014:72). Financial distress biasanya diawali dengan adanya situasi dimana perusahaan gagal membayar utang dan semakin banyak kegiatan perusahaan yang dibiayai oleh utang, akibat semakin besar kewajiban perusahaan untuk melunasi utang tersebut. Penelitian ini menggunakan rasio debt to assets (DAR) sebagai indikator leverage. Rasio DAR menggambarkan seberapa besar pengaruh utang terhadap aset perusahaan. Jika semakin banyak kegiatan perusahaan dibiayai oleh utang, ada kemungkinan bahwa perusahaan tidak dapat membayar utang dan kemungkinan perusahaan akan memiliki risiko gagal bayar yang akan memicu financial distress. Jadi, semakin tinggi nilai leverage menyebabkan kondisi financial distress pun tinggi. Penelitian Moleong (2018) menunjukkan bahwa leverage dapat memprediksi kondisi financial distress dengan arah positif sehingga penelitian tersebut dapat mendukung penelitian ini. $\mathrm{H}_{1} \quad$ : Leverage dapat memprediksi kondisi financial distress dengan arah positif.

Selanjutnya, penelitian ini menggunakan rasio likuiditas. Rasio likuiditas dapat diartikan sebagai rasio yang menilai kapabilitas perusahaan untuk membayar utang jangka pendeknya pada waktu yang telah ditentukan. Likuiditas menggambarkan kemampuan entitas untuk menutupi kewajiban jangka pendek perusahaan menggunakan aset lancar (Fahmi, 2014:65). Tingkat likuiditas yang tinggi akan mengurangi kemungkinan perusahaan gagal secara finansial. Ini berarti bahwa perusahaan akan memiliki kemampuan untuk membayar kewajibannya tepat waktu. Sebagian besar perusahaan yang tidak likuid akan menjadi bangkrut secara finansial dan akhirnya, bangkrut (Kristanti \& Effendi, 2017). Penelitian ini menggunakan current ratio (CR) sebagai indikator likuiditas. Jika perusahaan memiliki nilai rasio lancar yang tinggi, itu 
berarti perusahaan memiliki nilai aset lancar yang tinggi. Nilai aset lancar yang tinggi berarti ada aset yang tidak digunakan atau tidak terjual di perusahaan. Jika keberadaan aset yang tidak digunakan ini menyebabkan penjualan menurun, maka jika penjualan menurun, laba yang dihasilkan perusahaan akan turun juga. Penurunan laba akan memungkinkan perusahaan untuk menyebabkan financial distress. Jadi, semakin tinggi nilai likuiditas, maka dapat menyebabkan kondisi financial distress pun semakin tinggi. Penelitian Nurhidayah \& Rizqiyah (2018) menyatakan bahwa likuiditas dapat memprediksi kondisi financial distress dengan arah positif sehingga penelitian tersebut dapat mendukung penelitian ini. Hipotesis yang dapat dibentuk berdasarkan teori dan pengembangannya adalah sebagai berikut. $\mathrm{H}_{2} \quad$ : Likuditas dapat memprediksi kondisi financial distress dengan arah positif.

Selanjutnya, penelitian ini menggunakan rasio aktivitas. Rasio aktivitas menyatakan sebaik apa sebuah perusahaan memanfaatkan sumber daya yang dimiliki dengan tujuan mendukung kegiatan perusahaan agar kegiatan yang dilakukan menjadi maksimal dengan memperoleh hasil yang maksimal (Fahmi,
2014:77). Rasio ini disebut juga sebagai rasio pemanfaatan aset, yaitu rasio yang dipakai untuk menentukan efektivitas dan intensitas aset perusahaan dalam menghasilkan penjualan yang menyebabkan keuntungan (Aisyah, Kristanti, \& Zultilisna, 2017). Penelitian ini menggunakan total asset turnover (TATO) sebagai indikator dari aktivitas. Apabila perusahaan memiliki nilai total asset turnover yang tinggi itu berarti perusahaan telah memanfaatkan sumber daya berupa aset secara efektif sehingga dapat menghasilkan penjualan yang maksimal. Sebaliknya, apabila nilai total asset turnover rendah itu berarti perusahaan tidak dapat memanfaatkan aset sehingga berakibat penjualan yang tidak maksimal. Penjualan yang tidak maksimal ini akan membuat pendapatan turun dan akan berdampak pada probabilitas perusahaan mengalami kondisi financial distress. Jadi, semakin tinggi nilai rasio aktivitas itu berarti akan menurunkan kondisi financial distress pada suatu perusahaan. Penelitian Lisiantara \& Febrina (2018) menyatakan bahwa aktivitas dapat memprediksi kondisi financial distress dengan arah negatif sehingga penelitian tersebut dapat mendukung penelitian ini. Hipotesis yang dapat dibentuk berdasarkan teori 
dan pengembangannya adalah sebagai berikut. $\mathrm{H}_{3} \quad$ : Rasio aktivitas dapat memprediksi kondisi financial distress dengan arah negatif.

Selain rasio keuangan, faktor-faktor lainnya dapat digunakan seperti pada penelitian ini, menggunakan faktor ukuran perusahaan sebagai penentu kondisi financial distress. Ukuran perusahaan dapat diartikan sebagai suatu ukuran yang dapat mengkategorikan perusahaan besar dan kecil menurut berbagai cara, yaitu total aset penjualan, nilai pasar saham dan ratarata tingkat penjualan (Rahayu \& Sopian, 2017). Apabila total aset yang dimiliki perusahaan nilainya tinggi, perusahaan akan memiliki kondisi keuangan yang lebih stabil dan lebih kuat (Ayu, Handayani, \& Topowijono, 2017). Salah satu ukuran yang digunakan adalah dilihat dari total asetnya. Penelitian ini menggunakan total aset yang di logaritma-natural kan. Perusahaan yang memiliki ukuran perusahaan besar cenderung dapat stabil dan bertahan jika kondisi sekitarnya memburuk. Selain itu, jika sebuah perusahaan memiliki total aset yang tinggi berarti akan membuat perusahaan mudah untuk memperoleh dana dari pihak luar yang nantinya akan dipakai untuk membiayai kegiatan operasinya dan diharapkan mampu dalam melunasi kewajibannya di masa yang akan datang. Hal tersebut dapat meminimalkan perusahaan dari kondisi financial distress. Jadi, semakin tinggi ukuran perusahaan itu berarti akan menurunkan kondisi financial distress pada suatu perusahaan. Penelitian Kristanti \& Effendi (2017) menyatakan bahwa ukuran perusahaan dapat memprediksi kondisi financial distress dengan arah negatif sehingga penelitian tersebut dapat mendukung penelitian ini. Hipotesis yang dapat dibentuk berdasarkan teori dan pengembangannya adalah sebagai berikut. $\mathrm{H}_{4} \quad$ : Ukuran perusahaan dapat memprediksi kondisi financial distress dengan arah negatif.

Selanjutnya, faktor yang dapat memprediksi kondisi financial distress adalah biaya agensi manajerial. Para pemilik (principal) memiliki tujuan agar perusahaan mencapai tujuannya secara baik, oleh karena itu mereka mengeluarkan biaya untuk memantau dan mengendalikan kemampuan manajer (agen) sehingga para manajer dapat bekerja untuk kepentingan perusahaan (Asrin, 2018). Penelitian ini menggunakan perhitungan rasio biaya administrasi dan umum terhadap total 
penjualan. Biaya umum dan administrasi meliputi biaya gaji manajer, biaya perjalanan dinas, biaya hiburan, biaya eksekutif, biaya pembayaran kesejahteraan dan lain-lain. Biaya administrasi dan umum perlu dipantau penggunaannya oleh principal. Ketika manajer diberikan insentif yang lebih dari principal, manajer cenderung mengeluarkan biaya-biaya yang berlebih demi mencapai tujuan mereka masing-masing. Kondisi financial distress akan dialami perusahaan ketika penggunaan biaya yang berlebihan tersebut tidak menjamin tercapainya kinerja perusahaan menjadi baik dan menjadi tidak seimbang antara biaya yang dikeluarkan dengan penjualan yang didapat. Jadi, semakin tinggi nilai biaya agensi manajerial akan menyebabkan kondisi financial distress suatu perusahaan tinggi juga. Penelitian Rimawati et al., (2017) menyatakan bahwa biaya agensi manajerial dapat memprediksi kondisi financial distress dengan arah positif sehingga penelitian tersebut dapat mendukung penelitian ini. Hipotesis yang dapat dibentuk berdasarkan teori dan pengembangannya adalah sebagai berikut. H5 : Biaya agensi manajerial dapat memprediksi kondisi financial distress dengan arah positif.
Selanjutnya, faktor eksternal yang dapat menentukan kondisi financial distress adalah inflasi. Definisi dari inflasi adalah harga yang mengalami peningkatan dalam beberapa waktu dan terjadi pada semua kelompok barang dan jasa, jika hanya satu atau dua barang yang mengalami peningkatan harga tidak bisa dikatakan sebagai inflasi, kecuali harga yang meningkat menyebar atau mengakibatkan sebagian besar dari harga barang-barang lain meningkat (Hanafi \& Supriyadi, 2018). Apabila nilai inflasi dari tahun ke tahun mengalami kenaikan maka daya beli konsumen terhadap penjualan perusahaan akan berkurang. Hal tersebut dapat menyebabkan menurunnya pendapatan perusahaan. Jika dari tahun ke tahun perusahaan memiliki pendapatan yang menurun kemungkinan perusahaan tersebut akan mengarah pada kondisi financial distress. Jadi, semakin tinggi nilai inflasi akan menyebabkan kondisi financial distress suatu perusahaan tinggi juga Penelitian Nurhidayah \& Rizqiyah (2018) menunjukka bahwa inflasi dapat memprediksi kondisi financial distress dengan arah positif sehingga penelitian tersebut dapat mendukung penelitian ini. Hipotesis yang dapat dibentuk berdasarkan teori dan 
pengembangannya adalah sebagai berikut. kimia tahun 2009-2018. Sampel pada penelitian H6 : Inflasi dapat memprediksi kondisi ini berjumlah 81 perusahaan dan memakai financial distress dengan arah positif. metode purposive sampling, dengan kriteria

\section{METODE PENELITIAN}

Metode kuantitatif dan data time series digunakan pada penelitian ini. Data yang digunakan meliputi perusahaan aneka industri dan industri dasar kimia di BEI tahun 20092018. Pada penelitian ini, variabel independen yang digunakan adalah leverage, likuiditas, aktivitas, ukuran perusahaan, biaya agensi manajerial, dan inflasi sedangkan variabel dependennya adalah kondisi financial distress. Penelitian ini menggunakan data sekunder, yaitu data yang diambil dari laporan keuangan di website perusahaan tahun 2009-2018. Teknik analisis data yang digunakan adalah analisis survival. Analisis survival adalah istilah yang diterapkan pada alat statistik dinamis yang digunakan untuk menganalisis waktu sampai suatu peristiwa tertentu (Gepp \& Kumar, 2008.

Analisis ini berbeda dengan analisis lain karena memodelkan garis waktu dengan masalah pada suatu peristiwa yang terjadi (Gepp \& Kumar, 2008). Populasi pada penelitian ini adalah perusahaan aneka industri dan industri dasar perusahaan aneka industri dan industri dasar kimia yang terdaftar di Bursa Efek Indonesia dan perusahaan aneka industri dan industri dasar kimia yang mengeluarkan financial statement beserta laporan audit independen selama tahun 2009-2018. Setelah menggunakan purposive sampling diperoleh 81 perusahaan yang memenuhi kriteria yang telah disebutkan.

$$
\text { Model regresi yang digunakan }
$$

pada penelitian ini adalah model regresi cox proportional hazard. Model tersebut merupakan sub-disiplin dari analisis survival. Kristanti \& Isynuwardhana (2018) dalam penelitiannya merumuskan model regresi cox proportional hazard sebagai berikut:

$$
\begin{gathered}
h(t, x)=h_{0}(t) \exp \left(\beta_{1} L E V+\beta_{2} L I K+\beta_{3} A K T\right. \\
\left.+\beta_{4} \operatorname{SIZE}+\beta_{5} A G M+\beta_{6} I N F\right)
\end{gathered}
$$

\section{Dimana,}

$\mathrm{h}(\mathrm{t}, \mathrm{x})=$ risiko kematian individu wak-

tu $\mathrm{t}$ dengan karakteristik $\mathrm{x}$.

h_0 $(\mathrm{t}) \quad$ = fungsi hazard dasar.

$\beta_{-} \mathrm{i}=$ parameter dari model regresi.

LEV = leverage

LIK = likuiditas

AKT = aktivitas

SIZE = ukuran perusahaan

AGM = biaya agensi manajerial

INF $\quad=$ inflasi. 


\section{HASIL DAN PEMBAHASAN}

Langkah awal dalam menguji model regresi cox proportional hazard adalah dengan melakukan analisis deskriptif. Data yang telah digabungkan akan digunakan dan dianalisis tanpa bermaksud tanpa membentuk kesimpulan umum (Sugiyono, 2014:148).

Berdasarkan Tabel 2, diketahui bahwa nilai mean yang dimiliki variabel likuiditas kurang dari nilai standar deviasi, artinya data bervariasi dan cenderung relatif heterogen (tidak berkelompok) sedangkan nilai mean yang dimiliki variabel leverage, aktivitas, ukuran perusahaan, biaya agensi manajerial, inflasi lebih dari standar deviasi, artinya data tidak bervariasi dan cenderung relatif homogen (dalam kelompok).

Rasio leverage memiliki nilai mean 0,62323 dengan nilai standar deviasi 0,52091. Dilihat dari total 81 sampel yang digunakan, 2,191222 dengan nilai standar deviasi 2,97899.

perusahaan dengan nilai di atas mean berjumlah 28 perusahaan dan yang di bawah nilai mean berjumlah 53 perusahaan. Nilai terendah bernilai 0.0541 . Nilai tersebut dimiliki oleh PT Intanwijaya Internasional Tbk di tahun 2009, pada saat itu juga PT Intanwijaya Internasional Tbk mengalami distress. Nilai terendah tersebut disebabkan karena total hutang yang dimiliki sebesar Rp8.524.850.194,00 sedangkan total asset yang dimiliki sebesar Rp157.569.330.098,00. Nilai tertinggi bernilai 2.9785 yang dimiliki oleh PT Asia Pacific Fibers Tbk di tahun 2012, pada saat itu juga PT Asia Pacific Fibers Tbk mengalami distress. Nilai tertinggi tersebut disebabkan karena total utang yang dimiliki sebesar Rp11.614.551.000.000,00 sedangkan total asset yang dimiliki sebear Rp3.899.450.000.000,00.

Rasio likuiditas memiliki nilai mean Tabel 2.

Hasil Statistik Deskriptif

\begin{tabular}{lccccc}
\hline & N & Minimum & Maximum & Mean & Std. \\
\hline Financial Distress & 81 & 0 & 1 & & Deviation \\
Leverage & 81 & 0.0541 & 2.9785 & 0.62323 & 0.492 \\
Likuiditas & 81 & 0.2028 & 23.3972 & 2.191222 & 2.97899 \\
Aktivitas & 81 & 0.0970 & 4.5455 & 1.02989 & 0.70166 \\
Ukuran Perusahaan & 81 & 25.3059 & 33.4737 & 28.42322 & 1.62556 \\
Agency Cost & 81 & 0.0074 & 0.2289 & 0.05832 & 0.04719 \\
Inflasi & 81 & 0.0320 & 0.06970 & 0.04598 & 0.01384 \\
\hline
\end{tabular}

Sumber: data diolah menggunakan SPSS 23 (2020). 
Dilihat dari total 81 sampel yang digunakan, perusahaan dengan nilai di atas mean berjumlah 20 perusahaan dan yang di bawah nilai mean berjumlah 61 perusahaan. Nilai terendah bernilai 0.2028 . Nilai tersebut dimiliki oleh PT Asia Pacific Fibers Tbk di tahun 2012, pada saat itu juga PT Asia Pacific Fibers Tbk mengalami distress. Nilai terendah tersebut disebabkan karena total aset lancar yang dimiliki sebesar Rp2.292.182.000.000,00 sedangkan total utang jangka pendek yang dimiliki sebesar Rp11.300.280.000.000,00. Nilai tertinggi dari variabel likuiditas adalah 23.3972 yang dimiliki oleh PT Intanwijaya Internasional Tbk di tahun 2009, pada saat itu juga PT Intanwijaya Internasional Tbk mengalami distress. Nilai maksimum tersebut diakibatkan total aset lancar yang dimiliki bernilai Rp135.475.971.890,00 sedangkan total utang jangka pendek yang dimiliki bernilai Rp5.189.427.810,00.

Rasio aktivitas memiliki nilai mean 1,02989 dengan nilai standar deviasi 0,70166. Dilihat dari total 81 sampel yang digunakan, perusahaan dengan nilai di atas mean berjumlah 33 perusahaan dan yang di bawah nilai mean berjumlah 48 perusahaan Nilai terendah sebesar 0.0970. Nilai tersebut dimiliki oleh
PT Kertas Basuki Rachmat Indonesia Tbk di tahun 2010, pada saat itu juga PT Kertas Basuki Rachmat Indonesia Tbk mengalami distress. Nilai terendah tersebut disebabkan karena total penjualan yang dimiliki sebesar Rp76.279.430.933,00 sedangkan total aset yang dimiliki sebesar Rp786.163.546.488,00. Nilai tertinggi dari variabel aktivitas adalah 4.545 yang dimiliki oleh PT Alakasa Industrindo Tbk di tahun 2013, pada saat itu juga PT Alakasa Industrindo Tbk mengalami distress. Nilai tertinggi tersebut disebabkan karena total penjualan yang dimiliki sebesar Rp1.099.620.270.000,00 sedangkan total aset yang dimiliki sebesar Rp241.912.806.000,00

Ukuran perusahaan memiliki nilai mean 28,4232 dengan nilai standar deviasi 1,6255. Dilihat dari total 81 sampel yang digunakan, perusahaan dengan nilai di atas mean berjumlah 36 perusahaan dan yang di bawah nilai mean berjumlah 45 perusahaan. Nilai terendah sebesar 25,3059. Nilai tersebut dimiliki oleh PT Eratex Djaja Tbk di tahun 2009, pada saat itu juga PT Eratex Djaja Tbk mengalami distress. Nilai terendah tersebut disebabkan karena total aset yang dimiliki oleh perusahaan ini sebesar Rp97.776.000.000,00. Nilai tertinggi dari 
variabel ukuran perusahaan adalah 33,4737 yang dimiliki oleh PT Astra International Tbk di tahun 2018, tetapi PT Astra International Tbk tidak mengalami distress. Nilai tertinggi tersebut disebabkan karena total aset yang dimiliki sebesar Rp344.711.000.000,00.

Biaya Agensi Manajerial memiliki nilai rata-rata 0,05832 dengan nilai standar deviasi 0,04719. Dilihat dari total 81 sampel yang digunakan, perusahaan dengan nilai di atas mean berjumlah 26 perusahaan dan yang di bawah nilai mean berjumlah 55 perusahaan. Nilai terendah bernilai 0.0074. Nilai tersebut dimiliki oleh PT Tembaga Mulia Semanan Tbk di tahun 2013, pada saat itu juga PT Tembaga Mulia Semanan Tbk mengalami distress. Nilai terendah tersebut disebabkan karena biaya umum dan administrasi yang dimiliki oleh perusahaan ini sebesar Rp57.953.977.857,00 sedangkan total penjualan yang dimiliki perusahaan ini pada tahun 2013 sebesar Rp7.728.561.325.893,00. Nilai maksimum dari variabel biaya agensi manajerial adalah 0.2289 yang dimiliki oleh PT Multi Prima Sejahtera Tbk di tahun 2014, pada saat itu juga PT Multi Prima Sejahtera Tbk mengalami distress. Nilai maksimum tersebut disebabkan karena biaya umum dan administrasi yang dimiliki sebesar Rp16.055.130.084,00 sedangkan total penjualan yang dimiliki perusahaan ini tahun 2014 sebesar Rp70.155.000.000,00.

Inflasi dari sektor aneka industri dan sektor industri dasar kimia yang terdaftar di Bursa Efek Indonesia pada tahun 2009-2018 memiliki nilai mean 0,04598 dengan nilai standar deviasi 0,01384 . Dilihat dari total 81 sampel yang digunakan, perusahaan dengan nilai di atas mean berjumlah 43 perusahaan dan yang di bawah nilai mean berjumlah 38 perusahaan. Nilai terendah sebesar 0.032. Pada tahun 2018, Indonesia memiliki nilai rata-rata inflasi sebesar 0.032 atau 3,2\% dimana dalam kurung waktu sepuluh tahun nilai inflasi ini merupakan nilai terendah sehingga hanya sedikit perusahaan yang mengalami distress. Nilai tertinggi dari variabel inflasi adalah 0.06970. Di tahun 2013, rata-rata nilai inflasi yang terjadi di Indonesia adalah 0,0697 atau 6,97\% dimana dalam waktu kurun sepuluh tahun banyak perusahaan yang mengalami distress.

Langkah selanjutnya dalam menguji model ini adalah menguji parameter dengan menggunakan uji likelihood ratio atau uji G. Pengujian uji likelihood bertujuan untuk melihat 
pengaruh variabel yang dipakai terhadap model regresi (Marisa, Yozza, \& Maiyastri, 2017). Uji

likelihood ratio dapat dihitung menggunakan rumus sebagai berikut:

$$
\mathrm{G}=-2\left(\log \mathrm{L}_{0}-\log \mathrm{L}_{\mathrm{p}}\right)
$$

Dimana, Lo $=$ likelihood dari model tanpa variabel prediktor.

$\mathrm{L}_{\mathrm{p}}=$ likelihood dari model yang terdiri dari variabel prediktor.

Dimana hipotesis yang dirumuskan adalah sebagai berikut:

$H_{0}: \beta_{1}=\beta_{2}=\cdots=\beta_{p}=0$ (tidak ada satupun variabel independen mempengaruhi variabel dependen).

$H_{\mathrm{a}}$ : minimal ada satu dari $\beta \mathrm{i} \quad 0$, dengan $\mathrm{I}=$ $1,2, \ldots, p$ (minimal ada satu variabel independen yang berpengaruh secara simultan terhadap variabel dependen).

Kesimpulannya: jika $H_{0}$ ditolak maka $\beta_{\mathrm{i}} \quad 0$, artinya waktu survival atau variabel dependen dipengaruhi oleh minimal satu variabel independen yang dipakai.

Hasil uji likelihood ratio dapat dilihat pada Tabel 3. Berdasarkan Tabel 3, nilai likelihood dari model tanpa variabel prediktor adalah 398.108 sedangkan nilai likehood dari model terdiri dari variabel prediktor adalah 350.475 maka untuk pengujian parameter adalah -95.266 sehingga Ha diterima, yang berarti setidaknya ada satu variabel independen yang memengaruhi waktu hidup atau variabel dependen.

Langkah selanjutnya adalah menguji koefisien regresi. Nilai taraf signifikansi yang digunakan sebesar 0.05 atau 5\%, nilai tersebut dianggap sudah cukup dalam pengambilan keputusan dalam membandingkan variabel-variabel yang diuji.

Berdasarkan Tabel 4, dari pengujian persamaan regresi cox proportional hazard, maka diperoleh model sebagai berikut: $h(t, x)=h_{0}(t) \exp (0.447 L E V+0.013 L I K-0.355 A K T$ $-0.176 \mathrm{SIZE}+1.101 \mathrm{AGM}+62.010 \mathrm{INF})$

Variabel leverage yang diproksikan debt to assets ratio (DAR) memiliki koefisien regresi 0.447 yang menjelaskan setiap kenaikan 1 satuan pada nilai DAR maka akan membuat

Tabel 3

Hasil Uji Likelihood Ratio (Uji G)

\begin{tabular}{lc}
\hline & $\begin{array}{c}\text { Likelihood } \\
\text { Value }\end{array}$ \\
\hline Likelihood dari model tanpa variabel prediktor. & 398.108 \\
Likelihood dari model yang terdiri dari variabel prediktor & 350.475 \\
\hline
\end{tabular}

Sumber: data output SPSS 23 (2020). 
Tabel 4.

Variables in The Equation

\begin{tabular}{lcccccc}
\hline & B & SE & Wald & Df & Sig. & Exp(B) \\
\hline Leverage & 0.447 & 0.260 & 2.951 & 1 & 0.086 & 1.563 \\
Likuiditas & 0.013 & 0.061 & 0.049 & 1 & 0.825 & 1.014 \\
Aktivitas & -0.355 & 0.255 & 1.933 & 1 & 0.164 & 0.701 \\
Ukuran & -0.176 & 0.124 & 2.030 & 1 & 0.154 & 0.838 \\
$\begin{array}{l}\text { Perusahaan } \\
\text { Biaya Agensi }\end{array}$ & 1.101 & 3.270 & 0.113 & 1 & 0.736 & 3.007 \\
$\begin{array}{l}\text { Manajerial } \\
\text { Inflasi }\end{array}$ & 62.010 & 12.203 & 25.822 & 1 & 0.000 & $8.525 \mathrm{E}+26$ \\
\hline
\end{tabular}

Sumber: data output SPSS 23 (2020).

financial distress pada perusahaan mengalami kenaikan sebesar 0.447 satuan. Variabel likuiditas yang diproksikan current ratio (CR) memiliki koefisien regresi 0.013 yang menjelaskan setiap kenaikan 1 satuan pada nilai CR maka akan membuat financial distress pada perusahaan mengalami kenaikan sebesar 0.013 satuan. Variabel aktivitas yang diproksikan total asset turnover (TATO) memiliki koefisien regresi -0.355 yang menjelaskan kenaikan 1 satuan pada nilai TATO maka akan membuat financial distress pada perusahaan mengalami penurunan sebesar 0.355 satuan. Variabel ukuran perusahaan yang diproksikan dengan logaritma natural total aset memiliki koefisien regresi -0.176 yang menjelaskan setiap kenaikan 1 satuan pada nilai tersebut akan membuat financial distress pada perusahaan mengalami penurunan 0176. Variabel biaya agensi manajerial yang diproksikan dengan biaya administrasi dan umum dibagi penjualan memiliki koefisien regresi 1.101 yang menjelaskan setiap kenaikan 1 satuan pada nilai tersebut akan membuat financial distress pada perusahaan mengalami kenaikan 1.101. Variabel inflasi yang datanya diambil dari website resmi BI memiliki nilai koefisien regresi 62.010 yang menjelaskan setiap kenaikan 1 satuan pada nilai tersebut akan membuat financial distress pada perusahaan mengalami kenaikan sebesar 62.010 .

Nilai koefisien regresi dari X1 atau leverage adalah 0.447 dengan nilai signifikansi 0.086 lebih dari 0.05 , artinya, leverage tidak dapat memprediksi kondisi financial distress. Hipotesis penelitian yang menyatakan leverage dapat memprediksi kondisi financial distress dengan arah positif ditolak. Nilai koefisien 
regresi dari X2 atau likuiditas adalah 0.013 dengan nilai signifikansi 0.825 lebih dari 0.05 artinya likuiditas tidak dapat memprediksi kondisi financial distress. Hipotesis penelitian yang menyatakan likuiditas dapat memprediksi kondisi financial distress dengan arah positif ditolak. Nilai koefisien regresi dari $\mathrm{X} 3$ atau aktivitas adalah -0.355 dengan nilai signifikansi 0.164 lebih dari 0.05 , artinya rasio aktivitas tidak dapat memprediksi kondisi financial distress. Hipotesis penelitian yang menunjukkan aktivitas dapat memprediksi kondisi financial distress dengan arah negatif ditolak. Nilai koefisien regresi dari $\mathrm{X} 4$ atau ukuran perusahaan adalah -0.176 dengan nilai signifikansi 0.154 lebih dari 0.05 , artinya ukuran perusahaan tidak dapat memprediksi kondisi financial distress. Hipotesis penelitian yang menyatakan ukuran perusahaan dapat memprediksi kondisi financial distress dengan arah negatif ditolak. Nilai koefisien regresi dari X5 atau biaya agensi manajerial adalah 1.101 dengan nilai signifikansi 0.736 lebih dari 0.05 , artinya biaya agensi manajerial tidak dapat memprediksi kondisi financial distress. Hipotesis penelitian yang menyatakan biaya agensi manajerial dapat memprediksi kondisi financial distress dengan arah positif ditolak. Nilai koefisien regresi dari X6 atau inflasi adalah 62.010 dengan nilai signifikansi 0.000 lebih kecil dari 0.05 , artinya inflasi dapat memprediksi kondisi financial distress dengan arah positif. Hipotesis penelitian yang menyatakan inflasi dapat memprediksi kondisi financial distress dengan arah positif diterima.

Analisis model regresi cox proportional hazard menyatakan bahwa pada penelitian ini, leverage tidak dapat memprediksi kondisi financial distress. Leverage diproksikan dengan rasio DAR. Adanya kenaikan atau penurunan pada rasio DAR tidak berdampak akan kemungkinan sebuah perusahaan mengalami kondisi financial distress. Seperti contoh pada penelitian ini, PT Intanwijaya Internasional Tbk memiliki nilai DAR sebesar 0.0541 atau 5.41\% di tahun 2009. Nilai $5.41 \%$ dapat dikatakan sebagai nilai yang kecil bagi nilai DAR sebuah perusahaan tetapi dengan nilai DAR tersebut, PT Intanwijaya Internasional Tbk tetap mengalami kondisi financial distress ditahun 2009. Nilai DAR yang tinggi belum tentu berdampak akan potensi perusahaan mengarah pada kondisi financial distress. Apabila nilai DAR tinggi tetapi tidak diikuti dengan nilai beban usaha 
yang tinggi maka perusahaan dapat terhindar dari potensi terjadinya kondisi financial distress. Selain itu, apabila perusahaan dapat mengelola dan mengendalikan utang secara baik, potensi terjadinya kondisi financial distress tidak akan terjadi. Hal-hal tersebut yang menyebabkan leverage tidak memiliki pengaruh pada kondisi financial distress pada penelitian ini. Hasil penelitian ini didukung oleh hasil penelitian Pertiwi (2018) dan Putri \& Merkusiwati (2014

Hasil analisis regresi cox proportional hazard selanjutnya menunjukkan likuiditas tidak dapat memprediksi kondisi financial distress. Likuiditas diproksikan dengan current ratio (CR). Pada penelitian ini, nilai current ratio yang paling rendah dimiliki oleh $\mathrm{PT}$ Asia Pacific Fibers Tbk ditahun 2012 dengan angka 0.2028. Sesuai dengan pengembangan hipotesis yang telah disebutkan sebelumnya, perusahaan akan mengalami kondisi financial distress jika current ratio nya juga tinggi, tetapi nilai current ratio yang rendah pada PT Asia Pacific Fibers Tbk di tahun 2012 mengakibatkan perusahaan tersebut mengarah pada kondisi financial distress. Hal ini terjadi karena pada perhitungan current ratio terdapat akun aset lancar, dimana komponen utama dari aset lancar adalah persediaan dan piutang usaha. Perusahaan masing-masing memiliki caranya sendiri dalam mengubah persediaan dan piutang usaha menjadi kas untuk melunasi kewajiban lancarnya. Persediaan dan piutang usaha memiliki durasi yang panjang dan cara yang tidak sama tiap perusahaannya sehingga naik dan turunnya nilai likuiditas yang diproksikan dengan current ratio tidak akan berdampak pada potensi kondisi financial distress stress yang dialami perusahaan. Hasil penelitian didukung oleh Kristanti \& Isynuwardhana (2018) dan Pertiwi (2018).

Hasil analisis regresi cox proportional hazard selanjutnya menunjukkan rasio aktivitas tidak dapat memprediksi kondisi financial distress. Rasio aktivitas diproksikan dengan rasio total asset turnover (TATO). Pada pengembangan hipotesis penelitian, menyatakan bahwa semakin tinggi nilai TATO yang dimiliki oleh suatu perusahaan, maka perusahaan tersebut berhasil mengelola dan memanfaatkan asetnya sehingga penjualan yang dihasilkan pun akan meningkat sehingga potensi terjadinya kondisi financial distress pun terhindar. Pada penelitian ini, nilai TATO tertinggi dimiliki oleh PT Alakasa Industrindo 
Tbk di tahun 2013 tetapi secara bersamaan di tahun 2013 juga perusahaan tersebut mengalami kondisi financial distress. Penjualan yang tinggi belum tentu bersumber dari pemanfaatan aset yang baik, ada beberapa sebab yang membuat penjualan meningkat dan diikuti laba yang maksimal, yaitu dengan mengeluarkan biayabiaya kegiatan operasi dengan optimal dan sekecil-kecilnya. Pada PT Alakasa Industrindo Tbk di tahun 2013, beban pokok penjualan dari tahun sebelumnya meningkat sehingga menyebabkan perusahaan tersebut mengalami distress. Jadi, naik turunnya nilai rasio TATO belum tentu berdampak pada kemungkinan perusahaan mengalami kondisi financial distress. Hasil penelitian ini telah didukung oleh hasil penelitian Yustika et al., (2015) dan Aisyah et al., (2017).

Hasil analisis regresi cox proportional hazard selanjutnya menunjukkan ukuran perusahaan tidak dapat memprediksi kondisi financial distress. Setiap penurunan dan pertumbuhan ukuran perusahaan tidak berdampak pada potensi perusahaan mengarah pada kondisi financial distress. Perusahaan yang memiliki ukuran baik kecil maupun besar apabila didalamnya terdapat manajemen yang mengelola dan mengendalikan perusahaanya dengan baik sehingga kinerja yang dihasilkan setiap tahunnya optimal akan terhindar dari potensi terjadinya kondisi financial distress. Hasilpenelitianinitelah didukungolehpenelitian Rahayu \& Sopian (2017) dan Pertiwi (2018). Hasil analisis regresi cox proportional hazard selanjutnya menunjukkan biaya agensi manajerial tidak dapat memprediksi kondisi financial distress. Pada penelitian ini, nilai perhitungan biaya agensi manajerial dari perusahaan aneka industri dan industri dasar kimia bernilai kecil, dominan dibawah $15 \%$ meskipun beberapa perusahaan diatas $15 \%$, artinya perusahaan di kedua sektor tersebut telah mengeluarkan biaya-biaya yang seharusnya dikeluarkan secara optimal dan tidak berlebihan. Selain itu jika nilai biaya agensi manajerial tinggi, belum tentu ada manajer yang mengeluarkan biaya yang besar untuk keperluan masing-masing, melainkan untuk mencapai tujuan perusahaan itu sendiri. Hasil penelitian ini telah didukung oleh hasil penelitian Yustika et al. (2015) dan Asrin (2018). Hasil analisis regresi cox proportional hazard selanjutnya menunjukkan bahwa inflasi berpengaruh positif dan signifikan pada 
kondisi financial distress. Inflasi merupakan faktor eksternal dimana setiap perusahaan akan memiliki nilai yang sama tergantung pada nilai inflasi setiap tahunnya. Nilai inflasi yang tinggi menyebabkan perusahaan akan ikut menaikkan harga karena keadaan ekonomi suatu negara sehingga minat konsumen melakukan tranksasi jual beli pun menurun dan berdampak pada turunnya pendapatan bagi suatu perusahaan. Pendapatan yang menurun tersebut mengakibatkan keuntungan yang diperoleh perusahaan menurun sehingga peusahaan mengalami kondisi financial distress. Pada penelitian ini, nilai rata-rata inflasi terendah terjadi pada tahun 2018, yaitu sebesar 3.2\%. Di tahun 2018 pula perusahaan-perusahaan jarang mengalami kondisi financial distress karena nilai inflasi yang kecil. Berbeda dengan tahun 2013, yang memiliki nilai rata-rata inflasi sebesar 6.97\%. Selama tahun 2009-2018, tahun 2013 memiliki nilai rata-rata inflasi paling tinggi, maka dari itu di tahun 2013 banyak perusahaan yang mengalami kondisi financial distress. Hasil penelitian ini telah didukung oleh hasil penelitian Rohiman \& Damayanti (2019) dan Nurhidayah \& Rizqiyah (2018).

\section{SIMPULAN}

Berdasarkan hasil penelitian yang telah dilakukan pada perusahaan aneka industri dan industri dasar kimia yang terdaftar di Bursa Efek Indonesia tahun 2009-2018 dapat disimpulkan bahwa leverage, likuiditas, aktivitas, ukuran perusahaan, biaya agensi manajerial tidak dapat memprediksi kondisi financial distress yang artinya naik dan turunnya nilai variabel tersebut tidak akan berdampak pada kemungkinan perusahaan mengalami kondisi financial distress. Variabel inflasi dapat memprediksi kondisi financial distress dengan arah positif, artinya semakin tinggi nilai inflasi pada suatu negara akan berpotensi terjadinya kondisi financial distress pada perusahaan.

Berdasarkan kesimpulan yang telah dijelaskan, penulis memberikan saran bagi perusahaan agar terhindar dari kondisi financial distress, yaitu tetap melakukan pengawasan terhadap nilai inflasi yang terjadi karena inflasi yang tinggi dapat mengakibatkan perusahaan mengalami kondisi financial distress selain untuk perusahaan, bagi investor sebagai bahan pertimbangan dalam melakukan investasi pada sebuah perusahaan dengan mempertimbangkan faktor-faktor internal dan eksternal perusahaan 
seperti pada penelitian ini. Bagi penelitian selanjutnya, agar menggunakan variabel lain seperti mekanisme good corporate governance serta variabel makroekonomi lainnya seperti nilai tukar dan tingkat suku bunga dan menggunakan populasi sampel selain dari industri manufaktur, yaitu industri utama atau industri jasa karena kedua industri tersebut kontribusinya pada perekonomian nasional masih dibawah industri manufaktur.

\section{REFERENSI}

Agustini, N. W., \& Wirawati, N. G. P. (2019). Pengaruh Rasio Keuangan Pada Financial Distress Perusahaan Ritel Yang Terdaftar di Bursa Efek Indonesia (BEI). E-Jurnal Akuntansi, 26, 251.

Aisyah, N. N., Kristanti, F. T., \& Zultilisna, D. (2017). Pengaruh Rasio Likuiditas, Rasio Aktivitas, Rasio Profitabilitas, dan Rasio Leverage Terhadap Financial Distress. 4(1), 411-419.

Asrin, A. A. (2018). Pengaruh Leverage, Sales Growth, Biaya Agensi Manajerial dan Arus Kas Tehadap Financial Distress. Sekolah Tinggi Ilmu Ekonomi Perbanas, (1), 43.

Ayu, A., Handayani, S., \& Topowijono, T. (2017). Pengaruh Likuiditas, Leverage, Profitabilitas, dan Ukuran Perusahaan Terhadap Financial Distress (Studi pada Perusahaan Manufaktur Sektor Industri Dasar dan Kimia yang Terdaftar di Bursa Efek Indonesia tahun 2012-2015). Jurnal Administrasi Bisnis S1 Universitas Brawijaya, 43(1), 138-147.

Brahmana, R. K. (2007). Identifying Financial Distress Condition in Indonesia Manufacture Industry. Journal Business, 1-19.
Christine, D., Wijaya, J., Chandra, K., Pratiwi, M., Lubis, M. S., \& Nasution, I. A. (2019). Pengaruh Profitabilitas, Leverage, Total Arus Kas dan Ukuran Perusahaan terhadap Financial Distress pada Perusahaan Property dan Real Estate yang Terdapat di Bursa Efek Indonesia Tahun 2014-2017. Jesya (Jurnal Ekonomi \& Ekonomi Syariah), 2(2), 340-350.

Cinantya, I., \& Merkusiwati, N. (2015). Pengaruh Corporate Governance, Financial Indicators, Dan Ukuran Perusahaan Pada Financial Distress. E-Jurnal Akuntansi, 10(3), 897-915.

Elloumi, F., \& Gueyié, J. P. (2001). Financial distress and corporate governance: an empirical analysis. Corporate Governance: The international journal of business in society.

Fahmi, I. (2014). Analisis Laporan Keuangan. Bandung: Alfabeta.

Gepp, A., \& Kumar, K. (2008). The role of survival analysis in financial distress prediction. International research journal of finance and economics, 16(2008), 1334.

Hanafi, I., \& Supriyadi, S. G. (2018). Prediksi Financial Distress Perusahaan Manufaktur Yang Terdaftar Di Bursa Efek Indonesia. Jurnal Ekuivalensi, 4(1), 24-51.

Kristanti, F.,T. (2019). Financial Distress (Teori dan Perkembangannya Dalam Konteks Indonesia). Malang: Inteligensia Media.

Kristanti, F. T., \& Effendi, N. (2017). A Survival Analysis of Indonesian Distressed Company Using Cox Hazard Model. International Journal of Economics \& Management, 11.

Kristanti, F. T., \& Herwany, A. (2017). Corporate governance, financial ratios, political risk and financial distress: A survival analysis. Accounting and Finance Review (AFR) Vol, 2(2).

Kristanti, F. T., \& Isynuwardhana, D. (2018). How long are The Survival Time in the Industrial Sector of Indonesian Com- 
panies?. International Journal of Engineering \& Technology, 7(4.38), 856-860.

Kristanti, F. T., Rahayu, S., \& Huda, A. N. (2016). The determinant of financial distress on Indonesian family firm. Procedia-Social and Behavioral Sciences, 219, 440-447.

Lisiantara, G. A., \& Febrina, L. (2018). Likuiditas, Leverage, Operating Capacity, Profitabilitas, Growth Sebagai Preditor Financial Distress ( Studi Empiris Pada Perusahaan Manufaktur Yang Terdaftar Di Bursa Efek Indonesia Tahun 20132016 ). Prosiding SENDI, 978-979.

Marisa, M., Yozza, H., \& Maiyastri, M. (2017). Model Regresi Cox Proportional Hazard Pada Laju Tamat Mahasiswa Jurusan Matematika Universitas Andalas. Jurnal Matematika UNAND, VI(1), 33-41.

Moleong, L. C. (2018). Pengaruh Real Interest Rate dan Leverage Terhadap Financial Distress. Open Journal Systems, 30(1), 71-86.

Muflihah, I. Z. (2017). Analisis Financial Distress Perusahaan Manufaktur Di Indonesia dengan Regresi Logistik. Majalah Ekonomi, XXII(2), 254-269.

Nurhidayah, N., \& Rizqiyah, F. (2018). Kinerja Keuangan Dalam Memprediksi Financial Distress. Jurnal Ilmiah Bisnis Dan Ekonomi Asia, 11(2), 42-48.

Pertiwi, A. D. (2018). Pengaruh Rasio Keuangan, Growth, Ukuran Perusahaan, dan Inflasi Terhadap Financial Distress di Sektor Pertambangan Yang Terdaftar DI Bursa Efek Indonesia (BEI) Periode 2012-2016. Jurnal Ilmu Manajemen (JIM), 6(3), 359-366.

Platt, H. D., \& Platt, M. B. (2002). Predicting corporate financial distress: reflections on choice-based sample bias. Journal of economics and finance, 26(2), 184-199.

Purba, S. (2019). Pengaruh Kepemlikian Institusional, Intellectual Capital, dan Leverage Terhadap Financial Distress. JAFJournal Of Accounting And Finance, 2(2), 27-40. doi:10.25124/jaf.v2i2.2125.
Prastiwi, B. I., \& Dewi, R. (2019). Pengaruh Managerial Agency Cost Terhadap Financial Distress Dengan Struktur Kepemilikan Sebagai Variabel Pemoderasi. Jurnal Informasi, Perpajakan, Akuntansi, dan Keuangan Publik, 14(1), 81-104.

Putri, N. W. K. A., \& Merkusiwati, N. K. L. A. (2014). Pengaruh mekanisme corporate governance, likuiditas, leverage, dan ukuran perusahaan pada financial distress. E-Jurnal Akuntansi, 93-106.

Rahayu, W. P., \& Sopian, D. (2017). Pengaruh Rasio Keuangan dan Ukuran Perusahaan Terhadap Financial Distress (Studi Empiris Pada Perusahaan Food and Beverage di Bursa Efek Indonesia). Competitive, 33(2).

Rimawati, I., \& Darsono, D. (2017). Pengaruh Tata Kelola Perusahaan, Biaya Agensi Manajerial Dan Leverage Terhadap Financial Distress. Diponegoro Journal of Accounting, 6(3), 222-233.

Rohiman, S. F., \& Damayanti, C. R. (2019). Pengaruh Inflasi, Nilai Tukar Dan Suku Bunga Terhadap Financial Distress. Jurnal Administrasi Bisnis, 72(2), 186-195

Sugiyono, S. (2014). Metode Penelitian Pendidikan Pendekatan Kuantitatif, Kualitatif, dan R\&D. Bandung: Alfabeta.

Widhiari, N. L. M. A., \& Merkusiwati, N. K. L. A. (2015). Pengaruh rasio likuiditas, leverage, operating capacity, dan sales growth terhadap financial distress. E-Jurnal Akuntansi, 456-469.

Yustika, Y., Kirmizi, \& Sifli, A. (2015). Pengaruh Likuiditas, Leverage, Profitabilitas, Operating Capacity, dan Biaya Agensi Manajerial Terhadap Financial Distress. JOM FEKON, 2 No. 2, 1-15. 